\title{
A comparative survey of the results of analyses of blood serum in clinical chemistry laboratories in the United Kingdom
}

\author{
T. P. WhiteheAD, D. M. BROWNING, AND A. GREGORY
}

From the Wolfson Research Laboratories, Department of Clinical Chemistry, Queen Elizabeth Medical Centre, Birmingham 15

SYNOPSIS Since July 1969, portions of the same blood serum have been dispatched to clinical chemistry laboratories in the United Kingdom at 14-day intervals. The results of each serum survey were reported to each of the 390 participants within 11 days of their originally receiving the specimen.

During the first 18 months of the survey no overall improvement in the results was seen. Therefore a summary of each laboratory's ability consistently to produce results close to the mean of the method used was calculated and reported as a single figure, the variance index, and sent to all participants at regular intervals together with a histogram distribution of the variance indices of other participants. The subsequent improvement in the overall results is described.

In many countries portions of the same blood serum have been distributed to many laboratories to compare the results of analysis. In the United Kingdom at least two surveys have been made nationally (Wootton and King, 1953; Gowenlock, 1969), and surveys within various regions of the United Kingdom have been carried out from time to time by individuals and some have been stimulated by the Association of Clinical Biochemists (Broughton and Raine, 1969).

The results of most of the published surveys from this country and abroad are concerned with occasional distributions of material, perhaps at monthly or annual intervals. Usually there are delays, sometimes of many months before the results from all the laboratories are made known to the participants in the survey. This delay means that the information is not as useful as it would have been at the time of the survey. Control of accuracy and precision in the laboratory is not static and it is difficult to enquire into a failure of precision or accuracy which occurred many months before. In addition, the long intervals between the surveys make it difficult to assess the effects of the results on the precision and accuracy of the laboratories.

In most surveys the specimens distributed are lyophylized animal serum and this limits the types of analysis which may be surveyed. In addition there may be problems in the manufacture and reconstitution of the sera before analysis.

In an attempt to overcome some of the difficulties outlined above, a scheme called the UK National Received for publication 19 April 1973.
Quality Control Scheme was started in 1969. The main objectives of the scheme were as follows:

1 To send at 14-day intervals a portion of a bulked human serum to all those hospital laboratories in the UK which perform clinical chemistry analyses.

2 The survey should initially be concerned with 15 of the more commonly performed analyses. If a laboratory did not routinely perform all of the 15 analyses, this would not exclude it from participating in the Scheme.

3 The participating laboratories to return the results to the organizing laboratory in as short a time as possible and the results from all the laboratories to be available to the participants within 10 days of the specimen arriving in the participating laboratories.

4 To make participation voluntary and preserve anonymity.

5 To present the results in a manner that would enable the participants to make judgments of their performance, particularly in relation to the analytical method used.

6 To assess the role of automation, analytical methods, laboratory workload, and other factors possibly affecting accuracy and precision.

7 To assess if any improvement in precision and accuracy in the hospital laboratories of the UK occurred as a result of frequent surveys.

\section{Organization of the Scheme}

The scheme is administered from the Wolfson Research Laboratories, Queen Elizabeth Medical 
Centre in Birmingham. It involves part of the time of the chief technician and also two part-time workers who prepare and package the specimens and prepare and duplicate the reports for distribution.

\section{Growth of the Scheme}

In July 1969 the distribution of serum specimens to 200 laboratories in the UK was begun. The original list of laboratories was obtained by writing to those on the membership list of the Association of Clinical Biochemists. Over a period of time laboratories not included in the original list asked to participate. Within weeks the number of participating laboratories had increased to 250. Circulation of a letter to all laboratories which made statistical returns to the Department of Health and Social Security indicating that they performed more than 10000 biochemical tests per annum resulted in a further 120 laboratories commencing their participation in the survey early in 1970. At the present time the participants number 385. There is reason to think that the vast majority of laboratories within the National Health Service have entered the scheme and approximately $90 \%$ of participating laboratories return the results for each distribution of serum. At the present time the survey regularly includes 15 different chemical determinations. These are serum sodium, potassium, chloride, urea, glucose, calcium, phosphate, iron, total protein, albumin, bilirubin, alkaline phosphatase, cholesterol, uric acid, and creatinine. Not all 15 substances are required to be assayed for each distribution of serum. A group of eight tests alternates with a group of seven.

\section{Computer Facilities}

Although sufficient space is required for the preparation and packing of the material in the scheme, the essential equipment involved is a computer. The IBM 1130 computer in the authors' laboratory has been programmed to perform virtually all the clerical tasks involved in the scheme. The survey involves approximately two hours of computer time each fortnight.

\section{Serum Preparation}

Human serum has been used for distribution and this has been provided from excess test specimens obtained from hospital laboratories in the Birmingham area. In addition, supplies of unwanted serum have been obtained from the Blood Transfusion Centre in Birmingham. Approximately 3 litres of serum are required for each distribution. The sera are mixed well and Seitz filtered through grades $\mathbf{O}$,
2A, and 4 Carlson Ford filter pads. Occasionally chemical constituents are elevated by additions to the serum and these are made at this stage. After thorough mixing the serum is passed through a sterile HP/EKS sterilizing pad into a sterile flask and then dispensed aseptically into sterile plastic disposable tubes. Experience has shown that serum prepared in this way remains stable for the con- of stituents analysed for at least seven days at room temperature. Tests have shown that organisms are not present as judged by bacterial culture at $4^{\circ} \mathrm{C}$, $22^{\circ} \mathrm{C}$, and $37^{\circ} \mathrm{C}$ aerobically and anaerobically for 72 hours. It is imperative that the specimen distributed is sterile as the glucose and urea levels are quickly reduced by the slightest bacterial contamination. Every effort is made to exclude specimens from patients with infective hepatitis, but all participants are warned to treat the specimen as potentially contaminated.

\section{Time Table of Distribution of Sera and Results}

The distribution of sera is started by the printing of self-adhesive labels for each of the participating laboratories, ready for the labelling of the distribution packs (fig 1). This is printed on the computer line printer from a disc file which lists the addresses of the participating laboratories and also records their code number. The computer is also programmed to punch one card for each laboratory. The punched characters in the card are the participating laboratory's code number and the date of the serum specimen. The specimen of serum and the appropriate punched card are placed in a polystyrene box and an appropriately labelled postage sleeve is used to protect the tube and the punched card during transit (fig 1).

All packs are posted on Saturdays and almost

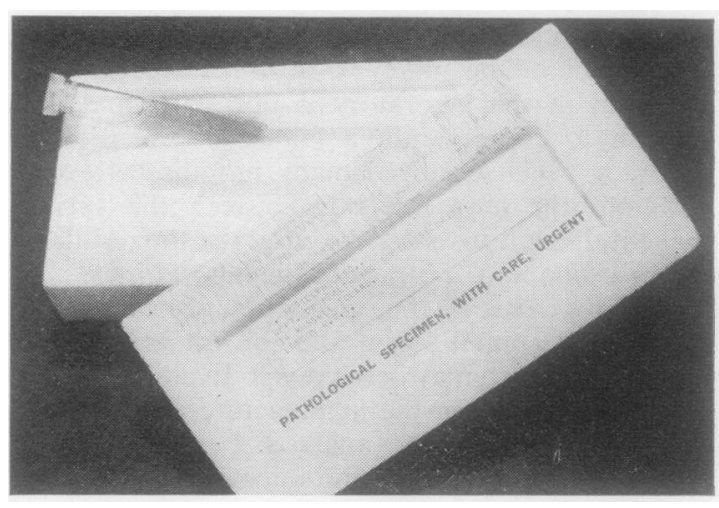

Fig 1 The polystyrene postal pack in which the serum is dispatched to participating laboratories. 


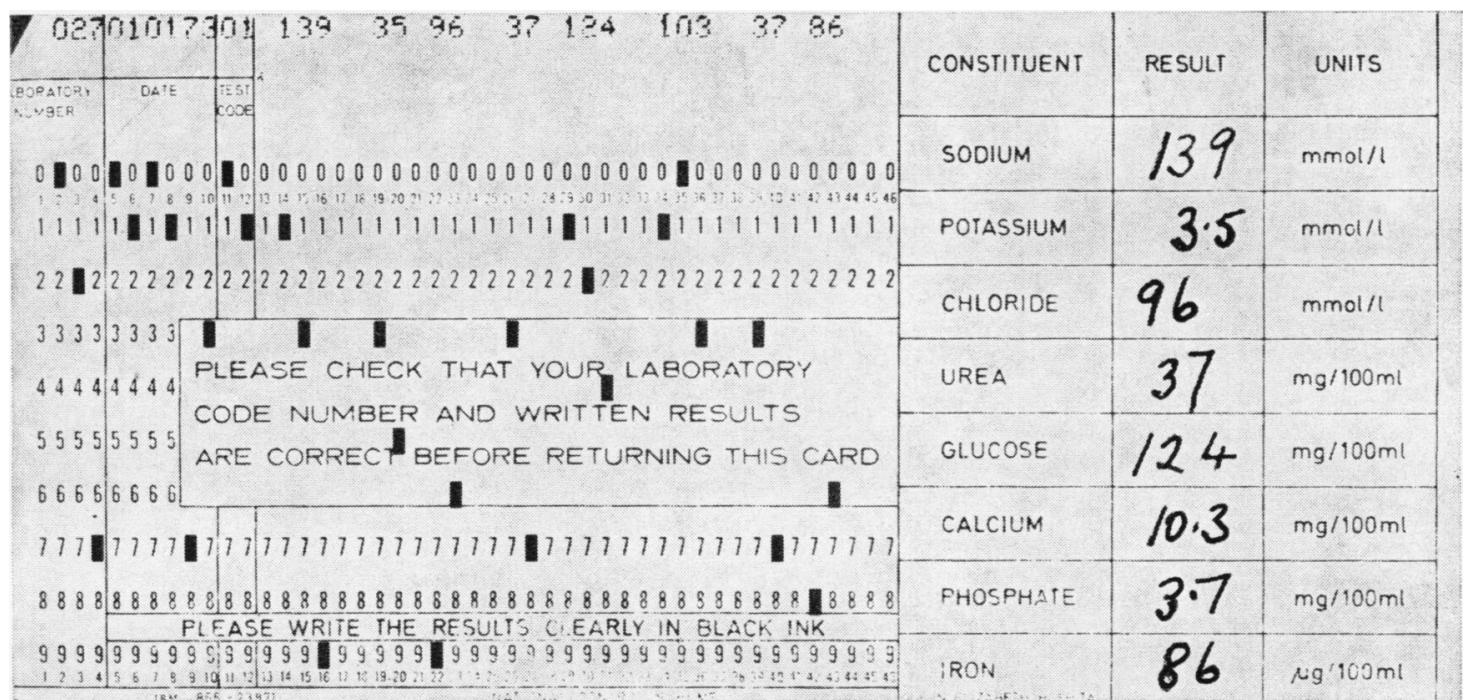

Fig 2 The punched card which accompanies each of the specimens distributed. The result column has been completed by the participating laboratory.

without exception arrive in the participating laboratories early on the following Monday morning (day 1). The laboratories perform the analyses listed on the punched card in their own manner (fig 2 ). The results are written on the card and returned in the polystyrene box to protect the card and conserve packing material. All results, if they are to be included in the statistical analysis, must be received by the following Monday (day 8 ). A preprinted address label is available for the return of results to the organizing laboratory, or for any further communication that the participants may wish to make. On day 8 all returned cards have the written results punched into them. Following verification they are analysed by the computer on the Tuesday (day 9). The computer printout of results, which is described later, is photocopied during the following day and the results are posted to the participating laboratories on the Wednesday (day 10), and usually reach the participants on the Thursday (day 11). The computer prepares a second batch of self-adhesive labels which are used to address the envelopes containing the results. This timing of distribution enables at least $90 \%$ of all participating laboratories to be included in the printout prepared on day 9 . The preparation of the serum and duplication of all results takes approximately 38 hours of labour each week; most of the labour is unskilled.

\section{Format of Report to all Participants}

The following is a description of the information provided in the computer printout. The computer lists the results attributed to each laboratory so that they may be checked for clerical errors by the participating laboratory. The mean, standard deviation, and coefficient of variation for each determination is calculated and printed. After removal of all results outside 3 standard deviations either side of the mean, these statistics are re-calculated, and these are termed the recalculated mean and standard deviation. A copy of this portion of the printout is shown in figure 3. This technique eliminates those results that are probably due to random errors such as clerical errors. The computer records and prints the number of results eliminated in this way. Following the statistical calculations, the printout shows histograms of the reported results for each determination. An example of such a histogram is shown in figure 4. The range of the histogram corresponds to the recalculated mean, $\pm 2 \mathrm{SD}$, as shown in figure 3 . A result within the limits is shown by a cross and a result outside these limits by a dot. These limits are not 'limits of acceptability' but are a convenient method of presenting the results, and it enables each participant to relate his results to all others returned.

The computer disk file contains information regarding the analytical methods in use by the participating laboratories for each determination and the results are classified according to the methods in use. These are presented as statistical summaries. Only results used in the calculation of the recalculated mean are included. The mean, standard deviation, and coefficient of variation are calculated for each method group and a summary is typed and included 


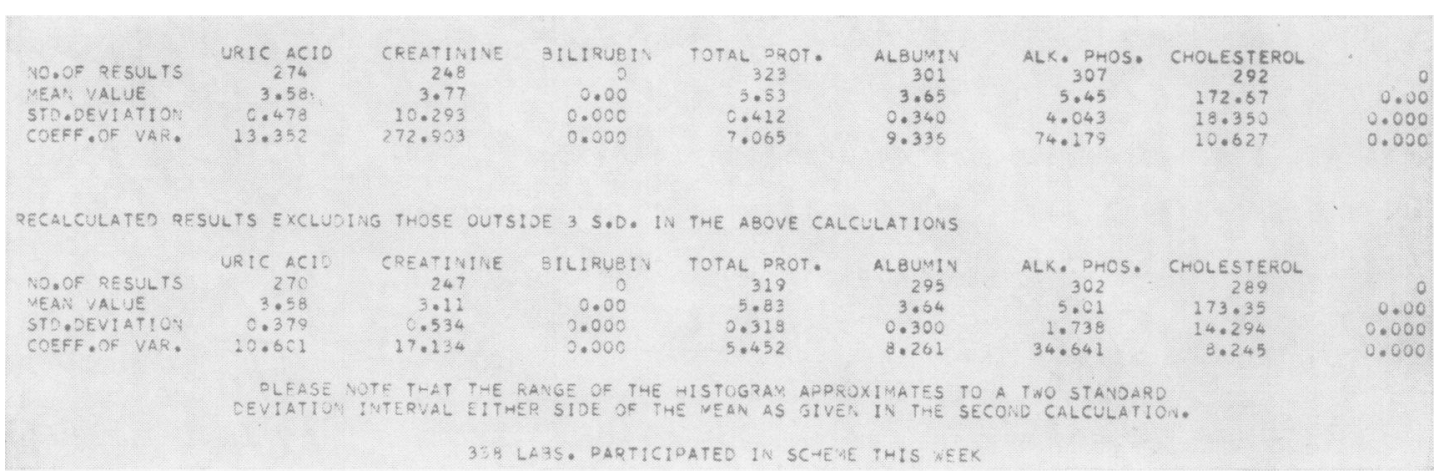

Fig 3

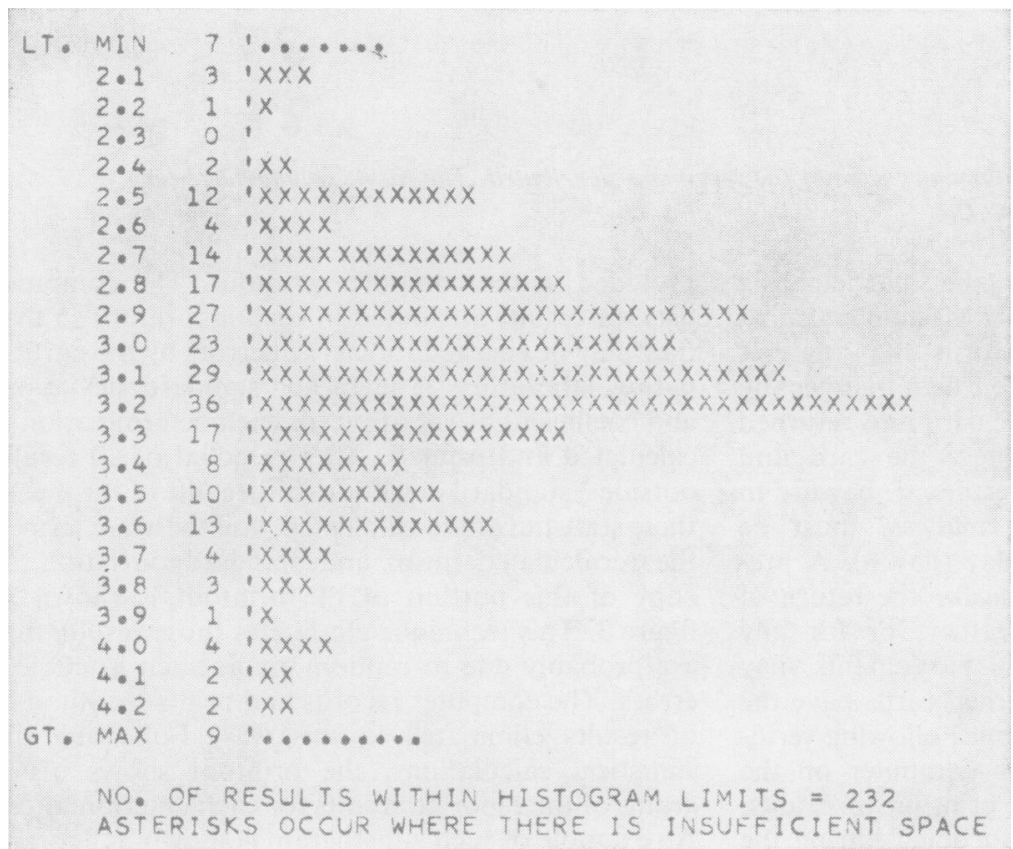

Fig 3 Example of the statistical results printed by computer for a particular distribution. (The $\subsetneq$ bilirubin level was below $1 \cdot 0$ $\mathrm{mg} / 100 \mathrm{ml}$, and the results werछ not included.)

Fig 4 An example of the histogram printed by computer. Each cross represents a result from a participating laboratory with \pm 2 standard deviations of the $\frac{\Phi}{8}$ mean. The dot represents results: outside these limits.

Fig 4

in the report received by each participant. Tables I to XV inclusive illustrate the format used for the presentation of the results according to analytical method.

\section{Results}

During this work approximately 70000 analyses have been performed and recorded. It would obviously be difficult to include all results in this report, and therefore some general comments and particular examples are used to illustrate certain aspects of the survey.
Table XVI lists the determinations performed and the number of sera distributed up to December 1971. 을 The range of mean values for the determinations, $\omega$ the mean coefficients of variation for all results,, and the upper and lower limits of the coefficient ofo variation for the recalculated results are shown.

Figures 5 to 9 inclusive illustrate in histogram? form a typical range of results for certain determin- $-\frac{T}{T}$ ations. The results for a particular distribution with $\frac{\vec{D}}{\mathrm{D}}$ a coefficient of variation in the middle of the range $\frac{\rho}{\rho}$ have been used.

Included in tables I to XV are the results classified according to the methods in use for the distributions $\Omega$ 


\begin{tabular}{lllc}
\hline & $\begin{array}{l}\text { Technicon } \\
\text { Flame Units }\end{array}$ & $\begin{array}{l}\text { EEL Flame } \\
\text { Units }\end{array}$ & $\begin{array}{l}\text { Other Flame } \\
\text { Units }\end{array}$ \\
\hline No. of results & 120 & 154 & 23 \\
Mean & 131.95 & 131.86 & 132.04 \\
SD & 1.71 & 3.55 & 2.70 \\
CV & 1.29 & 2.69 & 2.04 \\
\hline
\end{tabular}

Table I Results of sodium analysis using different methods (serum distributed 9 October 197I)

\begin{tabular}{lcll}
\hline & $\begin{array}{l}\text { Technicon } \\
\text { Flame Units }\end{array}$ & $\begin{array}{l}\text { EEL Flame } \\
\text { Units }\end{array}$ & $\begin{array}{l}\text { Other Flame } \\
\text { Units }\end{array}$ \\
\hline No. of results & 134 & 160 & 23 \\
Mean & 4.33 & 4.30 & 4.32 \\
SD & 0.11 & 0.17 & 0.25 \\
CV & 2.73 & 4.05 & 5.79 \\
\hline
\end{tabular}

Table II Results of potassium analysis using different methods (serum distributed 11 December 1971)

\begin{tabular}{lcll}
\hline & AutoAnalyzer & $\begin{array}{l}\text { EEL Chloride } \\
\text { Meter }\end{array}$ & Schale \& Schales \\
\hline No. of results & 131 & 79 & 72 \\
Mean & 97.10 & 96.93 & 98.13 \\
SD & 2.13 & 2.77 & 3.41 \\
CV & 2.20 & 2.86 & 3.47 \\
\hline
\end{tabular}

Table III Results of chloride analysis using different methods (serum distributed 11 September 1971)

\begin{tabular}{lcc}
\hline & AutoAnalyzer & Manual Urease \\
\hline No. of results & 228 & 71 \\
Mean & 45.42 & 47.30 \\
SD & 2.57 & 5.00 \\
CV & 5.67 & 10.58 \\
\hline
\end{tabular}

Table IV Results of urea analysis using different methods (serum distributed 11 September 1971)

\begin{tabular}{llc}
\hline & AutoAnalyzer & Manual \\
\hline No. of values & 105 & 157 \\
Mean & 3.82 & 3.83 \\
SD & 0.25 & 0.37 \\
CV & 6.71 & 9.71 \\
\hline
\end{tabular}

Table VII Results of phosphate analysis using different methods (serum distributed 11 September 1971)

\begin{tabular}{|c|c|c|c|}
\hline & AutoAnalyzer & Manual Ramsay & Manual Batho \\
\hline $\begin{array}{l}\text { No. of values } \\
\text { Mean } \\
\text { SD } \\
\text { CV }\end{array}$ & $\begin{array}{l}82 \\
77 \cdot 50 \\
12 \cdot 06 \\
15 \cdot 56\end{array}$ & $\begin{array}{l}47 \\
78 \cdot 73 \\
18 \cdot 41 \\
23 \cdot 38\end{array}$ & $\begin{array}{l}60 \\
80 \cdot 50 \\
13 \cdot 68 \\
16 \cdot 99\end{array}$ \\
\hline
\end{tabular}

Table VIII Results of iron analysis using different methods (serum distributed 13 November 1971)

\begin{tabular}{lcll}
\hline & AutoAnalyzer & $\begin{array}{l}\text { Manual } \\
\text { Colorimetric }\end{array}$ & $\begin{array}{l}\text { Manual } \\
\text { Uricase }\end{array}$ \\
\hline No. of results & 112 & 123 & 26 \\
Mean & 5.56 & 5.45 & 5.26 \\
SD & 0.35 & 0.55 & 0.44 \\
CV & 6.33 & 10.20 & 8.44 \\
\hline
\end{tabular}

Table IX Results of uric acid analysis using different methods (serum distributed 25 September 1971)

\begin{tabular}{lcc}
\hline & AutoAnalyzer & Manual \\
\hline No. of results & 121 & 133 \\
Mean & 4.66 & 4.57 \\
SD & 0.31 & 0.53 \\
CV & 6.75 & 11.81 \\
\hline
\end{tabular}

Table X Results of creatinine analysis using different methods (serum distributed 8 January 1972)

\begin{tabular}{llcccc}
\hline & $\begin{array}{l}\text { AutoAnalyzer } \\
\text { Reduction }\end{array}$ & $\begin{array}{l}\text { AutoAnalyzer } \\
\text { Glucose Oxidase }\end{array}$ & $\begin{array}{l}\text { Manual Folin } \\
\text { and Wu }\end{array}$ & $\begin{array}{l}\text { Manual Other } \\
\text { Copper Reduction }\end{array}$ & $\begin{array}{l}\text { Manual Glucose } \\
\text { Oxidase }\end{array}$ \\
\hline No. of values & 148 & 40 & 19 & 19 & 59 \\
Mean & 110.64 & 114.30 & 114.47 & 116.68 & $113 \cdot 13$ \\
SD & 9.02 & $10 \cdot 18$ & 13.82 & 11.77 & $10 \cdot 20$ \\
CV & 7.48 & 8.90 & 12.07 & 10.09 & 9.01 \\
\hline
\end{tabular}

Table V Results of glucose analysis using different methods (serum distribution 9 October 1971)

\begin{tabular}{|c|c|c|c|c|c|c|}
\hline & AutoAnalyzer & EDTA Titration & Atomic Absorption & Trinder & Clarke \& Collip & Others \\
\hline $\begin{array}{l}\text { No. of values } \\
\text { Mean } \\
\text { SD } \\
\text { CV }\end{array}$ & $\begin{array}{c}112 \\
9 \cdot 38 \\
0 \cdot 33 \\
3 \cdot 56\end{array}$ & $\begin{array}{l}84 \\
9 \cdot 33 \\
0 \cdot 43 \\
4 \cdot 62\end{array}$ & $\begin{array}{l}48 \\
9 \cdot 36 \\
0 \cdot 37 \\
4 \cdot 01\end{array}$ & $\begin{array}{l}21 \\
9 \cdot 69 \\
0 \cdot 52 \\
5 \cdot 38\end{array}$ & $\begin{array}{l}19 \\
9 \cdot 56 \\
0 \cdot 41 \\
4 \cdot 37\end{array}$ & $\begin{array}{c}16 \\
9 \cdot 36 \\
0 \cdot 58 \\
6 \cdot 28\end{array}$ \\
\hline
\end{tabular}

Table VI Results of calcium analysis using different methods (serum distributed 5 February 1972) 


\begin{tabular}{|c|c|c|c|c|c|c|}
\hline & AutoAnalyzer & $\begin{array}{l}\text { Manual Malloy } \\
\& \text { Evelyn }\end{array}$ & $\begin{array}{l}\text { Manual Lathe } \\
\text { and Ruthven }\end{array}$ & $\begin{array}{l}\text { Manual King } \\
\text { and Coxon }\end{array}$ & Manual Powell & Spectrophoto \\
\hline $\begin{array}{l}\text { No. of results } \\
\text { Mean } \\
\text { SD } \\
\text { CV }\end{array}$ & $\begin{array}{l}39 \\
2 \cdot 73 \\
0 \cdot 47 \\
17 \cdot 33\end{array}$ & $\begin{array}{l}94 \\
2 \cdot 40 \\
0 \cdot 66 \\
27 \cdot 61\end{array}$ & $\begin{array}{l}31 \\
2 \cdot 29 \\
0 \cdot 71 \\
31 \cdot 12\end{array}$ & $\begin{array}{l}33 \\
2 \cdot 42 \\
0 \cdot 58 \\
24 \cdot 09\end{array}$ & $\begin{array}{l}52 \\
2 \cdot 28 \\
0 \cdot 60 \\
26 \cdot 61\end{array}$ & $\begin{array}{l}3 \\
2 \cdot 49 \\
0 \cdot 60 \\
24 \cdot 33\end{array}$ \\
\hline
\end{tabular}

Table XI Results of bilirubin analysis using different methods (serum distributed 24 July 1971)

\begin{tabular}{|c|c|c|c|c|}
\hline & AutoAnalyzer Biuret & Manual Biuret & Refractometer & Specific Gravity \\
\hline No. of results & 124 & 153 & 10 & 4 \\
\hline Mean & 7.01 & 6.96 & 6.87 & $6 \cdot 87$ \\
\hline SD & $0 \cdot 30$ & 0.31 & 0.21 & $0 \cdot 14$ \\
\hline $\mathrm{CV}$ & $4 \cdot 34$ & $4 \cdot 58$ & $3 \cdot 12$ & $2 \cdot 18$ \\
\hline
\end{tabular}

Table XII Results of total protein analysis using different methods (serum distributed 23 October 1971)

\begin{tabular}{|c|c|c|c|c|c|}
\hline & AutoAnalyzer BCG & AutoAnalyzer $H A B A$ & Salt Fractionation and Biuret & Electrophoresis & Manual BCG \\
\hline No. of results & 74 & 21 & 106 & 42 & 33 \\
\hline Mean & $4 \cdot 27$ & $4 \cdot 39$ & $4 \cdot 39$ & $4 \cdot 19$ & $4 \cdot 13$ \\
\hline SD & $0 \cdot 27$ & $0 \cdot 38$ & 0.46 & 0.34 & 0.31 \\
\hline $\mathrm{CV}$ & $6 \cdot 50$ & $8 \cdot 64$ & $10 \cdot 50$ & $8 \cdot 28$ & $7 \cdot 49$ \\
\hline
\end{tabular}

Table XIII Results of albumin analysis using different methods (serum distributed 27 November 1971)

\begin{tabular}{|c|c|c|c|c|c|c|}
\hline & AutoAnalyzer & Manual King Kind & Manual King Armstrong & Warner & Phosphastrate & Bessey, Lowry, Brock \\
\hline No. of results & 99 & 64 & 75 & 43 & & 9 \\
\hline Mean & $7 \cdot 55$ & 6.26 & 6.62 & $6 \cdot 57$ & & 6.43 \\
\hline SD & $1 \cdot 37$ & i. 09 & $1 \cdot 56$ & $1 \cdot 25$ & & 1.79 \\
\hline CV & $18 \cdot 24$ & $17 \cdot 40$ & 23.62 & $19 \cdot 15$ & & $27 \cdot 92$ \\
\hline
\end{tabular}

Table XIV Results of alkaline phosphatase analysis using different methods (serum distributed 28 March 1972)

\begin{tabular}{lccc}
\hline & AutoAnalyzer & $\begin{array}{l}\text { Manual } \\
\text { L. Burchard }\end{array}$ & Manual Zak \\
\hline No. of results & 43 & 93 & 49 \\
Mean & 202.51 & 202.47 & $198 \cdot 10$ \\
SD & 11.68 & 17.29 & 18.40 \\
CV & 5.76 & 8.54 & $9 \cdot 29$ \\
\hline
\end{tabular}

Table XV Results of cholesterol analysis using different methods (serum distributed 25 September 1971)

of serum illustrated in histogram form in figures 5 to 9 .

\section{Results of the Survey 1969-1970}

The primary purpose of this survey was to give a service to laboratories so that they could assess their own performance and make their own judgments. The scheme was and is strictly anonymous, and only members of the computer staff in the author's laboratory know the identity of individual labora- tories. The secondary purpose was to attempt to $\stackrel{0}{3}$. influence those laboratories having poor results to improve their analytical standards.

The results of the survey from July 1969 to December 1970 showed a disturbing situation. The results indicated that by any analytical or clinical $\frac{7}{0}$ standard the discrepancies between laboratories and within any particular analytical method were $\mathcal{O}$ considerable. What was even more disturbing was $\mathrm{N}$ the fact that the survey had shown unsatisfactory N results for a period of about 18 months without there being any statistically demonstrable improvement in the results. Certain methods had been shown to have less variance than others and yet there was little change in technique or methods by participating laboratories.

A study of the mean levels of many determinations using various analytical methods indicated that the overall spread of results appeared to be due to a failure in precision rather than differences in the mean results of the various techniques and methods used. 


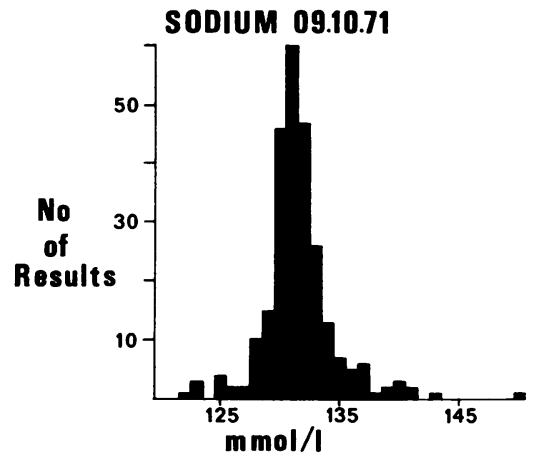

Fig 5 Typical histogram of the sodium results (serum distributed 9 October 1971).

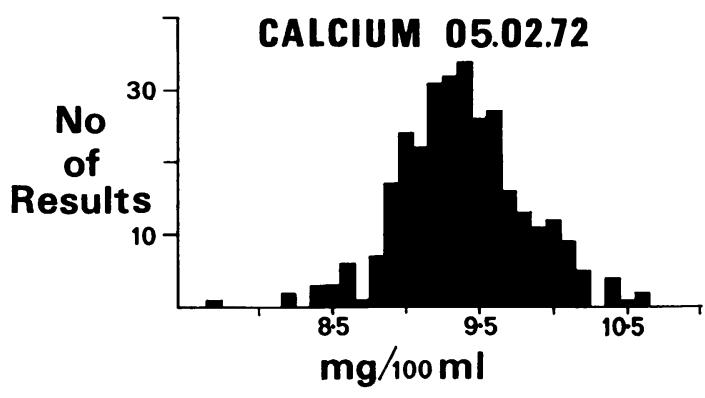

Fig 6 Typical histogram of the calcium results (serum distributed 5 February 1972).

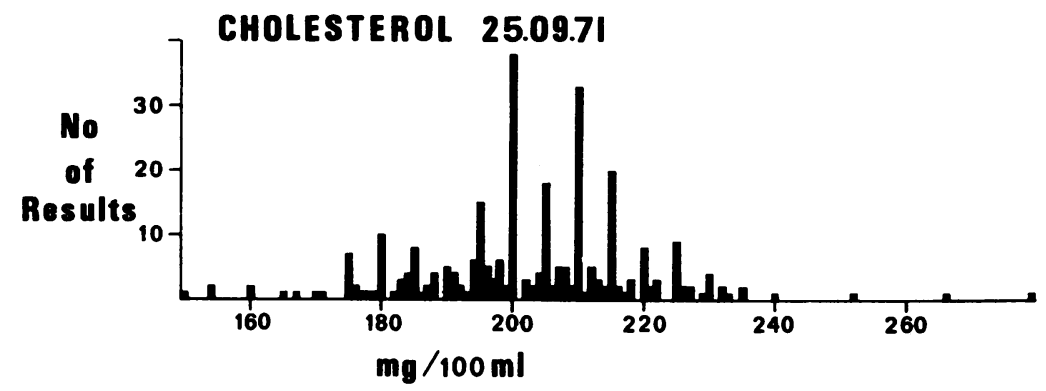

Fig 7 Typical histogram of the cholesterol results (serum distributed 25 September 1971).

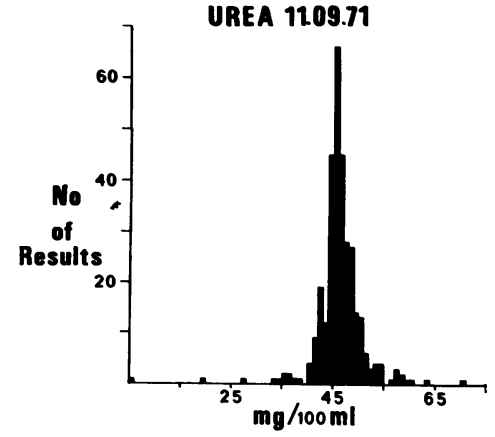

Fig 8 Typical histogram of the urea results (serum distributed 11 September 1971).

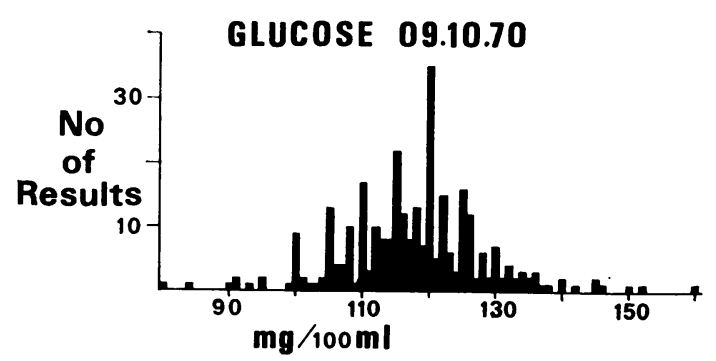

Fig 9 Typical histogram of the glucose results (serum distributed 9 October 1970). 


\begin{tabular}{|c|c|c|c|c|c|c|c|}
\hline \multirow[t]{3}{*}{ Determination } & \multirow{3}{*}{$\begin{array}{l}\text { Total No. of Sera } \\
\text { Distributed }\end{array}$} & \multicolumn{2}{|c|}{ Range of Mean Values All Results } & \multirow{3}{*}{$\begin{array}{l}\text { Mean Coefficient } \\
\text { of Variance All } \\
\text { Results }\end{array}$} & \multicolumn{3}{|c|}{ Recalculated Coefficient of Variance } \\
\hline & & \multirow[t]{2}{*}{ From } & \multirow[t]{2}{*}{ To } & & \multirow[t]{2}{*}{ Mean } & \multicolumn{2}{|l|}{ Range } \\
\hline & & & & & & From & To \\
\hline Sodium & 21 & $119 \cdot 29$ & $145 \cdot 09$ & $2 \cdot 60$ & $2 \cdot 14$ & $1 \cdot 70$ & $2 \cdot 89$ \\
\hline Potassium & 21 & $3 \cdot 20$ & 8.59 & 4.99 & 3.98 & $3 \cdot 30$ & $5 \cdot 12$ \\
\hline Chloride & 21 & $78 \cdot 49$ & $121 \cdot 74$ & $2 \cdot 90$ & $2 \cdot 56$ & $2 \cdot 24$ & $3 \cdot 31$ \\
\hline Urea & 21 & $29 \cdot 87$ & $155 \cdot 27$ & $9 \cdot 54$ & $8 \cdot 39$ & $6 \cdot 31$ & $17 \cdot 14$ \\
\hline Glucose & 13 & $58 \cdot 43$ & $176 \cdot 49$ & $12 \cdot 15$ & $9 \cdot 24$ & $7 \cdot 68$ & 13.52 \\
\hline Calcium & 19 & $7 \cdot 37$ & 13.03 & 6.57 & $5 \cdot 16$ & $4 \cdot 01$ & 6.92 \\
\hline Phosphate & 19 & 3.04 & $5 \cdot 21$ & $12 \cdot 19$ & $9 \cdot 09$ & $7 \cdot 74$ & $14 \cdot 41$ \\
\hline Iron & 13 & $78 \cdot 87$ & $146 \cdot 36$ & $21 \cdot 53$ & $17 \cdot 62$ & $15 \cdot 03$ & $21 \cdot 53$ \\
\hline Uric acid & 17 & $3 \cdot 56$ & 6.72 & $11 \cdot 10$ & 9.99 & 8.95 & $11 \cdot 49$ \\
\hline Creatinine & 17 & 1.03 & $7 \cdot 25$ & $21 \cdot 35$ & $15 \cdot 51$ & $9 \cdot 53$ & $20 \cdot 89$ \\
\hline Bilirubin & 7 & 0.70 & 3.47 & $37 \cdot 07$ & 28.92 & $19 \cdot 18$ & $35 \cdot 35$ \\
\hline Total protein & 7 & $6 \cdot 46$ & 6.97 & $5 \cdot 23$ & $4 \cdot 59$ & $4 \cdot 47$ & $4 \cdot 79$ \\
\hline Albumin & 7 & 3.49 & $4 \cdot 34$ & $10 \cdot 28$ & $9 \cdot 32$ & $8 \cdot 80$ & $11 \cdot 14$ \\
\hline \multicolumn{8}{|l|}{ Alkaline phos- } \\
\hline phatase & 7 & $7 \cdot 66$ & $14 \cdot 54$ & $43 \cdot 99$ & $23 \cdot 07$ & $22 \cdot 48$ & $23 \cdot 42$ \\
\hline Cholesterol & 11 & $188 \cdot 36$ & 203.02 & $12 \cdot 38$ & $10 \cdot 11$ & $8 \cdot 72$ & $11 \cdot 12$ \\
\hline
\end{tabular}

Table XVI Statistical summary of the results for the survey (July 1969-December 197I)

\begin{tabular}{|c|c|c|c|c|c|c|c|}
\hline \multirow[t]{2}{*}{ Determination } & \multicolumn{7}{|c|}{ Serum Number } \\
\hline & 1 & 2 & 3 & 4 & 5 & 6 & 7 \\
\hline Sodium (mmol/1) & Nil & -1 & Nil & Nil & Nil & Nil & Nil \\
\hline Potassium (mmol/l) & $-0 \cdot 1$ & Nil & $\mathrm{Nil}$ & $-0 \cdot 2$ & $-0 \cdot 1$ & $\mathrm{Nil}$ & Nil \\
\hline Chloride (mmol/1) & $\mathrm{Nil}$ & Nil & Nil & -1 & Nil & +1 & $\mathrm{Nil}$ \\
\hline Urea $(\mathrm{mg} / 100 \mathrm{ml})$ & -1 & -1 & -1 & -1 & $\mathrm{Nil}$ & +1 & Nil \\
\hline Glucose $(\mathrm{mg} / 100 \mathrm{ml})$ & Nil & Nil & -3 & -3 & -3 & -3 & Nil \\
\hline Calcium (mg/100 ml) & $+0 \cdot 1$ & -0.1 & $+0 \cdot 1$ & $\mathrm{Nil}$ & Nil & -0.1 & $\mathrm{Nil}$ \\
\hline Phosphate $(\mathrm{mg} / 100 \mathrm{ml})$ & $\mathrm{Nil}$ & Nil & $-0 \cdot 1$ & $-0 \cdot 2$ & Nil & Nil & Nil \\
\hline Iron $(\mu \mathrm{g} / 100 \mathrm{ml})$ & Nil & -2 & -2 & -6 & Nil & +4 & +7 \\
\hline Uric acid $(\mathrm{mg} / 100 \mathrm{ml})$ & -0.1 & $\mathrm{Nil}$ & $-0 \cdot 1$ & $-0 \cdot 1$ & -0.3 & - & - \\
\hline Creatinine $(\mathrm{mg} / 100 \mathrm{ml})$ & Nil & Nil & Nil & - & - & - & - \\
\hline Bilirubin $(\mathrm{mg} / 100 \mathrm{ml})$ & -0.1 & $-0 \cdot 1$ & Nil & Nil & - & - & - \\
\hline Total protein $(\mathrm{mg} / 100 \mathrm{ml})$ & $+0 \cdot 1$ & Nil & $-0 \cdot 1$ & Nil & Nil & - & - \\
\hline Cholesterol $(\mathrm{mg} / 100 \mathrm{ml})$ & Nil & $+0 \cdot 1$ & Nil & Nil & Nil & - & - \\
\hline
\end{tabular}

Table XVII Differences between the mean and the mode for the substance determined in the survey

The seven sera were chosen at random.

The true result for any particular determination was unknown; rarely in clinical chemistry is it known. The significance of the mean value for a particular method was also unknown. However, as more information became available, it was apparent that the mean value was more useful than was at first thought.

In fact, a surprising feature of the results was the close agreement between the mean results for the same constituents using various analytical techniques with widely differing chemical principles. In addition the symmetry of the distribution of results was illustrated by the closeness of the mode and the mean. Table XVII makes this comparison for the various determinations performed in the scheme. It can be seen that, in the majority of results, the mean and mode are close. The two exceptions are glucose and iron.

The glucose methods used by participants do give significantly different mean results (table V). The mean-mode difference in serum iron is probably due to the very high variation in virtually all the methods and techniques used. In table VI the collecting together of unclassified methods as 'others' is not really satisfactory, but even the grouping of several miscellaneous methods has resulted in a mean value surprisingly close to other methods. Evidence that mean values are 'true' values would be welcome, but this information is not available.

Although the scheme was anonymous, using individual laboratory code numbers it was possible to show that certain laboratories usually obtained 
results close to their method mean result whilst others produced results with differences that were not consistent. There was also a tendency for laboratories which had poor results by any method to have poor precision for all determinations.

It was concluded that the failure to achieve any overall improvement in the variance of results by this survey technique might be due to the method of displaying the results and their interpretation by participants. The reports distributed did not summarize any laboratory's ability to produce precise results over the whole range of determinations and for a period of time. It was therefore decided to summarize the achievement of each laboratory in one figure, a calculation termed the 'variance index', and to compare the results for individual laboratories.

\section{Calculation of Variance Index}

The overall standard deviation for each determination was calculated, and results outside $3 \times \mathrm{SD}$ were excluded and the 'recalculated SD' was used as an overall measure of variance.

Each result from a laboratory was classified according to the method. used and the 'method mean' calculated after excluding those outside $3 \times$ SD.

Each result was then allocated a score as follows:
Actual result - method mean

$$
\text { Recalculated SD }=
$$

If this calculation result was less than $1, \quad$ score 0 If this calculation result was between 1 and 2, score 1 If this calculation result was between 2 and 3 , score 2 If this calculation result was between 3 and 4, score 3 If this calculation result was greater than 4 , score 4

These scores were accumulated and the "variance index' was calculated as follows:

\section{$\frac{\text { Total score }}{\text { Total no. of analyses performed }}=$ VI}

In January 1971 the variance index spread for all laboratories was from 0.03 to 1.34 with a mean value of $0 \cdot 43$.

The variance index could be related to the workload. Laboratories were grouped according to the number of routine analyses performed annually and the variance indices calculated. The results of this grouping are shown in fig 10, and they indicate that those laboratories with a smaller workload were less able to produce results consistently close to the overall mean results for their method than the larger laboratories.

The recalculated standard deviation used in the variance index calculation was later replaced by a fixed coefficient of variation, and the values used are

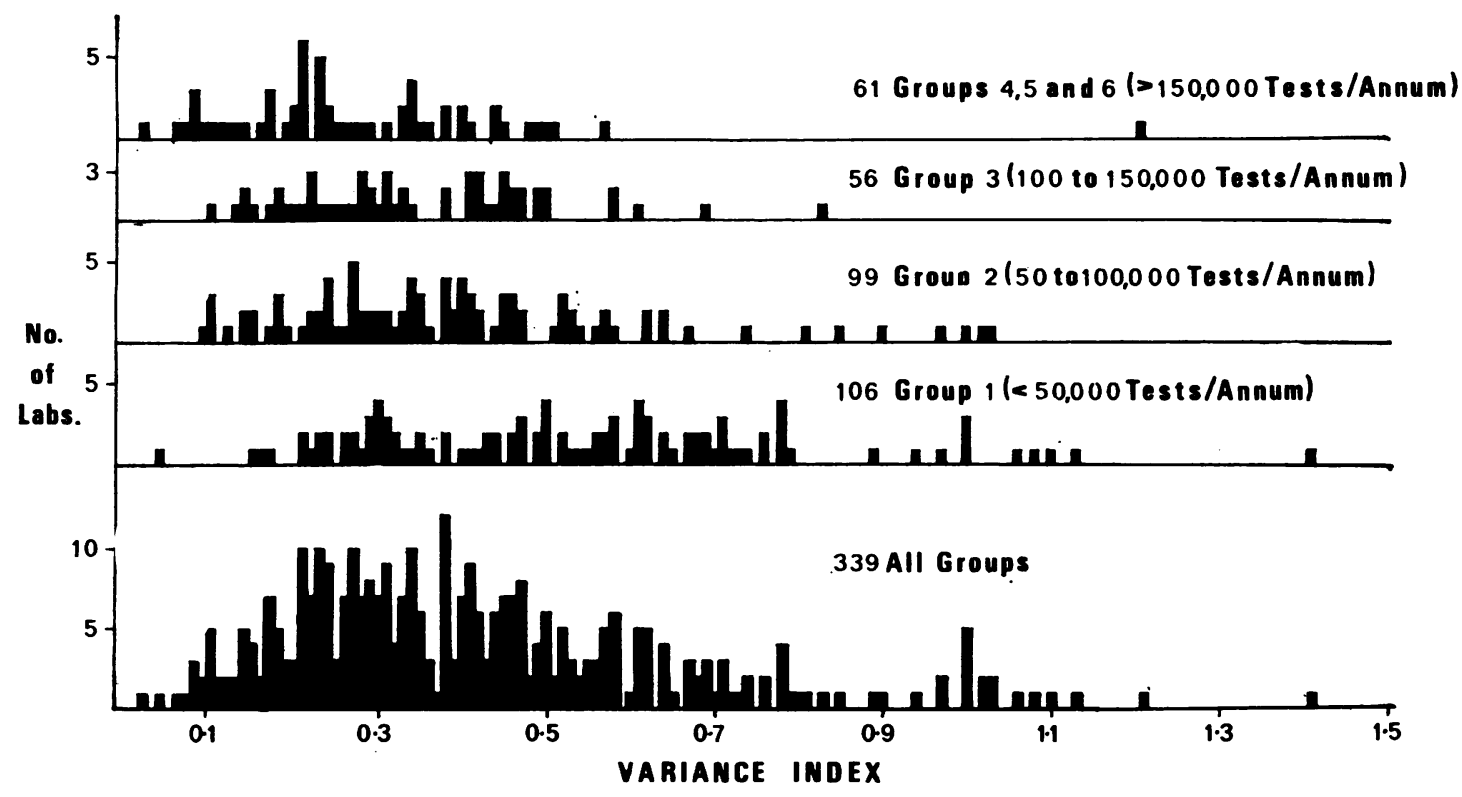

Fig 10 Histogram of the variance index for various workload groups (January 1971). 


\begin{tabular}{lrlrlr}
\hline Sodium & 2.32 & Calcium & 6.94 & Bilirubin & 26.24 \\
Potassium & 4.02 & Phosphate & 9.83 & Total protein & 4.64 \\
Chloride & 2.50 & Iron & 15.97 & Albumin & 9.35 \\
Urea & 8.39 & Uric acid & 10.51 & Alkaline phos- & \\
& & & & phatase & 23.37 \\
Glucose & 9.03 & Creatinine & 15.97 & Cholesterol & 10.64
\end{tabular}

Table XVIII The coefficients of variation used for the variance index calculation

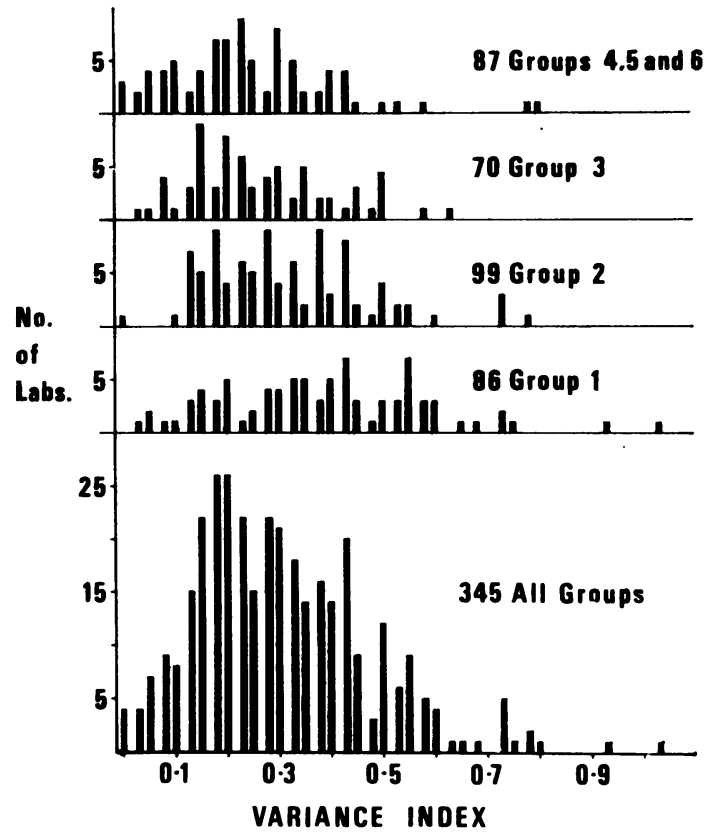

Fig 11 Histogram of the variance index for various workload groups (March 1972). recorded in table XVIII. This was done to avoid the possibility that the variance index would not improve due to the overall improvement of the standard deviation.

With the use of computer filing facilities it was possible to calculate a 'running variance index' from the last $\mathbf{4 0}$ analyses performed by any one laboratory. Thus any improvement in variance index could be assessed. This running variance index has been distributed to all participants at regular intervals.

Gradually the performance of laboratories as demonstrated by decreasing variance indices improved. The histogram of the variance index by June 1972 indicated a considerable improvement (fig 11).

In January 1971 the calculation of the variance index showed that only 45 laboratories had indices below $0 \cdot 20$. This number had increased to 86 by July 1972. In January 1971 no less than 41 laboratories had indices greater than 0.70, and by July 1972 this had decreased to 16 .

Figure 12 shows the mean running variance index for all laboratories and for three groups of laboratories, those in groups 1,3 , and 6 performing less than $50000,100-150000$, and more than 250000 biochemical tests per annum respectively. It can be seen that the running variance index has improved gradually since this introduction of a regular distribution to each participant of a report containing its own variance index and a histogram distribution of all the variance indices (figs 10 and 11). Each laboratory is able to relate its overall performance to that of all participants and particularly to those with a similar workload to itself.

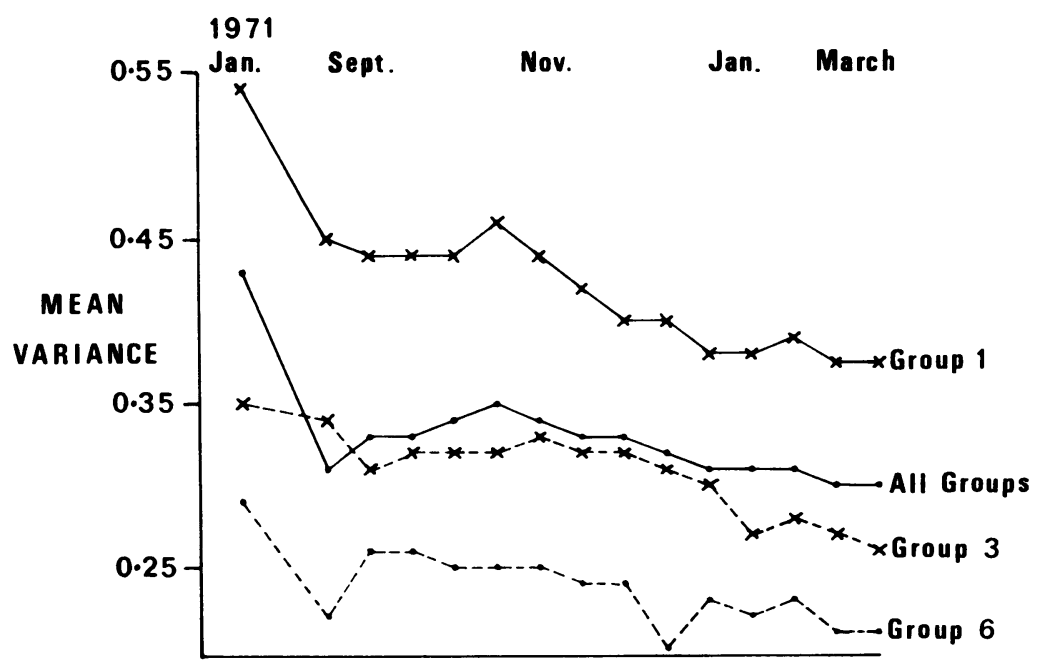

Fig 12 The improvement in the mean running variance index for laboratories in workload groups 1,3 , and 6 , and also for all laboratories over the period January 1971 to March 1972. 


\section{Discussion}

It is common practice for clinical chemistry laboratories to use quality control techniques to monitor their analytical variance. Over the last few years there have been considerable increases in the use of such techniques. The variances found in this survey are much greater than any of the participants would allow for their individual laboratory; this is the experience of other surveys.

It has been frequently presumed in studies of this type that the high variance is due to the use of different methods. This survey does not confirm such presumptions. The variances found in this survey could be explained on the basis of differences in the chemical standards used to standardize each method or technique. Some unpublished work amongst Birmingham hospital laboratories indicate that such differences do not make a significant contribution to inter-laboratory variance.

A third possible explanation is that the methods of monitoring laboratory variance in individual laboratories do not truly reflect the variance of the methods used. This is not an implied criticism of the use of such techniques (they are essential) but it is postulated that some laboratories design their own quality control techniques to give comfort rather than information on analytical variance.

This survey emphasizes the important role of inter-laboratory surveys in assessing the true variance between laboratories.

The maintenance of accuracy and precision in laboratory work is a difficult task demanding scientific skill. As judged by this survey, in general the laboratories with the larger workloads appear to have a lower variance than the laboratories with the smaller workloads. However, certain laboratories with smaller workloads attain better variance indices than some laboratories with larger workloads. The factors involved must be complex, involving combinations of problems in the use of laboratory apparatus and the personnel involved.

The variance of laboratories using automation is, in general, better than those using manual techniques, but not invariably so. One of the laboratories with an extremely high variance index appears to use automation for many of the analyses performed.

Most of the larger hospital laboratories use automatic equipment, and thus it is not possible to dissociate completely high workload and automation as factors in attaining good precision.

The absence of improvement before the variance index calculation was introduced is probably due to laboratory workers failing to interpret correctly the results of this survey. Subsequently most laboratories have improved, especially those with variance indices greater than 0.75 before 1971 .

It is probable that more general improvement in certain of the results, eg, sodium and potassium, would be difficult to achieve. However, there is room for improvement in many of the assays. Two determinations, cholesterol and iron, appear to have inherent problems which are reflected in the high variance for these analyses for most of the laboratories participating in the scheme.

This work was financed by the Equipment, Research and Development Fund of the Department of Health and Social Security. It was carried out under the auspices of the Standardization and Quality Control Subgroup of the Laboratory Development Advisory Group of the Department of Health and Social Security, and the authors are grateful to the members of this Subgroup for their advice.

The computer work was carried out under the direction of Margaret Peters. Nina Frazer, Sarah Colles, Linda Darby, and Hilary Fuller all played an integral part in the work by their enthusiasm, effort, and hard work.

\section{References}

Broughton, P. M. G., and Raine, N. (Editors) (1969). Quality control in clinical biochemistry. Ann. clin. Biochem., 6, 89-147.

Gowenlock, A. H. (1969). Results of an interlaboratory trial in Britain. Ann, clin. Biochem., 6, 126-133.

Wootton, I. D. P., and King, E. J. (1953). Normal values for blood constituents; inter-hospital differences. Lancet, 1, 470-471. 